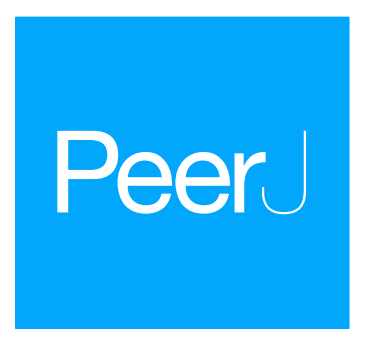

Submitted 24 March 2018

Accepted 27 June 2018

Published 02 August 2018

Corresponding author

Ronnie Von S. Veloso,

ronnievond@yahoo.com.br

Academic editor

Kalliat Valsaraj

Additional Information and Declarations can be found on page 15

DOI 10.7717/peerj.5275

Copyright

2018 Rodrigues et al.

Distributed under

Creative Commons CC-BY 4.0

OPEN ACCESS

\section{Evaluation of buriti endocarp as lignocellulosic substrate for second generation ethanol production}

\author{
Plínio R. Rodrigues ${ }^{1}$, Mateus F.L. Araújo ${ }^{1, *}$, Tamarah L. Rocha ${ }^{1, *}$, \\ Ronnie Von S. Veloso ${ }^{2}$, Lílian A. Pantoja ${ }^{1, *}$ and Alexandre S. Santos ${ }^{3, *}$ \\ ${ }^{1}$ Institute of Science and Technology, Federal University of Jequitinhonha and Mucuri Valleys, Diamantina, \\ Minas Gerais, Brazil \\ ${ }^{2}$ Graduate Program in Biofuels, Federal University of Jequitinhonha and Mucuri Valleys, Diamantina, Minas \\ Gerais, Brazil \\ ${ }^{3}$ Department of Basic Sciences, Federal University of Jequitinhonha and Mucuri Valleys, Diamantina, Minas \\ Gerais, Brazil \\ These authors contributed equally to this work.
}

\section{ABSTRACT}

The production of lignocellulosic ethanol is one of the most promising alternatives to fossil fuels; however, this technology still faces many challenges related to the viability of the lignocellulosic alcohol in the market. In this paper the endocarp of buriti fruit was assessed for ethanol production. The fruit endocarp was characterized physically and chemically. Acid and alkaline pre-treatments were optimized by surface response methodology for removal of hemicellulose and lignin from the biomass. Hemicellulose content was reduced by $88 \%$ after acid pretreatment. Alkaline pretreatment reduced the lignin content in the recovered biomass from $11.8 \%$ to $4.2 \%$ and increased the concentration of the cellulosic fraction to $88.5 \%$. The pre-treated biomass was saccharified by the action of cellulolytic enzymes and, under optimized conditions, was able to produce $110 \mathrm{~g}$ of glucose per L of hydrolyzate. Alcoholic fermentation of the enzymatic hydrolyzate performed by Saccharomyces cerevisiae resulted in a fermented medium with $4.3 \%$ ethanol and a yield of product per substrate $\left(\mathrm{Y}_{\mathrm{P} / \mathrm{S}}\right)$ of 0.33 .

Subjects Agricultural Science, Bioengineering, Biotechnology, Food, Water and Energy Nexus Keywords Bioethanol, Mauritia flexuosa, Saccharification, Pretreatment

\section{INTRODUCTION}

The growth of human population, depletion of fossil fuels and rising concerns about the anthropic impact on the environment have encouraged the search for renewable sources for cleaner energy production (Severo, Guimarães \& Dorion, 2018; Sarkar et al., 2012). In this context, lignocellulosic biomasses are a promising feedstock for liquid biofuels syntheses, alternative to petroleum-based fuels (Saini, Saini \& Tewari, 2015).

The technology for the production of second generation $(2 \mathrm{G})$ bioethanol, or lignocellulosic ethanol, has evolved in the last decades and functioning industrial plants already exist in some parts of the world, nevertheless; this biofuel still faces challenges of feedstock access, supply chain infrastructure, and price competitiveness with petroleum industry (UNCTAD, 2016). 
Lignocellulosic ethanol can be obtained from fermentation of hexose and pentose derived from the polysaccharides constituting plants cell walls and requires additional operations to those normally applied to produce first generation ethanol (Zabed et al., 2016). Lignin removal and hemicellulose hydrolysis, followed by cellulose saccharification, are necessary steps to provide fermentable sugars offered to specialized microorganisms to produce 2G ethanol (Maurya, Singla \& Negi, 2015; Guo, Chang \& Lee, 2018). There is a large set of biomass being evaluated as raw materials for this nascent industry, with emphasis on agroindustrial residues (Macedo et al., 2011; Hoa, Ngob \& Guo, 2014; Dominguez-Bocanegra, Torres-Muñoz \& López, 2015).

Buritizeiro (Mauritia Flexuosa) is one of the most abundant species of palm tree in Brazil, its occurrence covers the Cerrado and Amazon national biomes. Its fruit (Buriti) is elliptical to oval in shape and comprised of pericarp (bark), mesocarp (pulp), endocarp (seed shell lignocellulosic tissue), and endosperm (seed) (Sampaio \& Carrazza, 2012; Virapongse et al., 2017). Buriti fruits are economically exploited for a variety of purposes, such as edible and cosmetic oil extraction, and manufacturing of beverages, flours and ice creams (Lorenzi et al., 2004; Manzi \& Coomes, 2009; Gilmore, Endress \& Horn, 2013).

The market demand for the fruit is growing (Virapongse et al., 2017), however; the endocarp fruit portion presents few alternatives for commercial use, having low economic value. Buriti fruit production in north and northeast of Brazil, main regions of production in the country, is estimated at 70,000 tons per harvest (Bovi, 2015), and its endocarp is a possible source for the production of $2 \mathrm{G}$ ethanol, since it is an abundant waste of buritizeiro palm exploitation and does not directly require the availability of more cultivation lands (Van, Brose \& Schenkel, 2011; Bos et al., 2016).

Also, buriti endocarp use does not present competition with food market chains and embodies potential income generation, representing an alternative for communities living from the buriti fruit to access cleaner energy sources and to achieve a certain degree of energy independence.

In this paper, buriti fruit endocarp was physically and chemically characterized and evaluated for $2 \mathrm{G}$ ethanol production. Pre-treatments with dilute sulfuric acid and sodium hydroxide, and enzymatic saccharification were performed using response surface methodology. The effects of the factors studied in the pre-treatment and in the enzymatic hydrolysis were evaluated and the optimal conditions were highlighted. Ultimately, saccharified cellulose from buriti endocarp was fermented to ethanol using Saccharomyces cerevisiae.

Cellulose fraction of the buriti endocarp is surrounded by a matrix of hemicellulose and lignin, which together promote steric hindrance on the cellulose saccharification process. Chemical treatments, such as dilute acid and alkaline hydrolysis, are considered to be the most suitable for the commercial scale hemicellulose and lignin removal, increasing exposure of cellulase target sites on cellulose (Sims et al., 2009; Aditiya et al., 2016). 


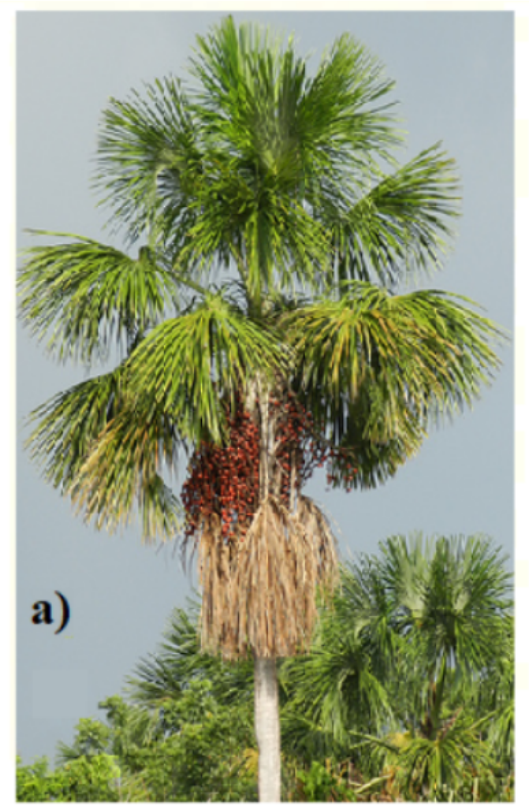

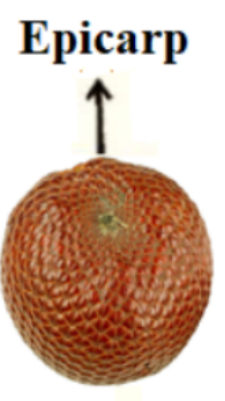

b)

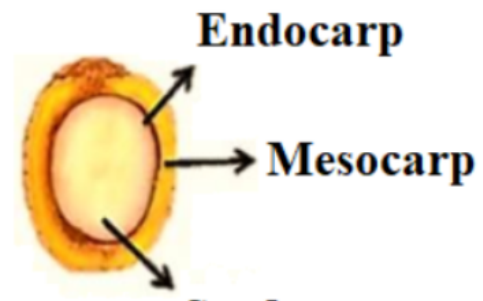

Seed c)

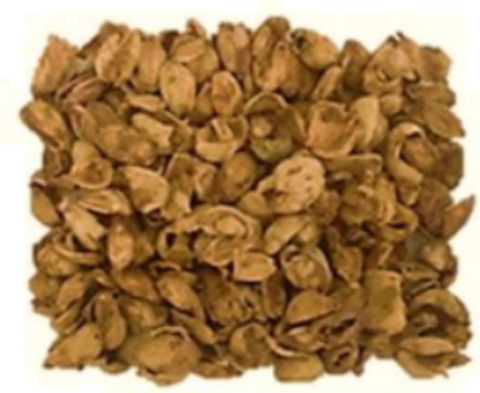

d)

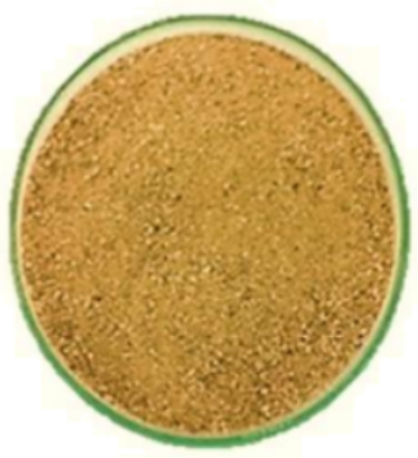

Figure 1 Appearance of Mauritia flexuosa $\mathrm{L}$ palm tree (A), its whole and sectioned fruits, and their (B), dry (C) and ground endocarps (D). Photo credit: Plínio R. Rodrigues

Full-size DOI: 10.7717/peerj.5275/fig-1

\section{MATERIAL AND METHODS}

\section{Physical characterization of buriti fruits}

Twenty kilograms of fruits were collected in Três Marias city, in Minas Gerais, Brazil. The physical characterization was performed on 50 randomly selected fruits. The fruits were weighed in the analytical balance, with an accuracy of $0.1 \mathrm{mg}$, and their longitudinal and transversal diameters were measured with the aid of a digital caliper, with an accuracy of $0.02 \mathrm{~mm}$. Results were expressed with two decimals. The endocarp of each fruit was separated manually with the aid of a steel knife (Tramontina) and weighed. After separation, the endocarps were oven dried with forced air ventilation at $60{ }^{\circ} \mathrm{C}$ for $24 \mathrm{~h}$, ground with a manual grinder (B03-Botini), manually sieved for particle size standardization, between 40 and 20 mesh ( 0.42 to $0.84 \mathrm{~mm}$ ), and stored in polyethylene bags at room temperature, protected from light (Fig. 1). 


\section{Chemical characterization of buriti fruit endocarp}

The ground endocarps were characterized in terms of total moisture, ashes, proteins, lipids, crude fiber, starch, total soluble sugars (TSS), cellulose, hemicellulose and lignin contents. All experiments were executed in three replicates.

\section{Moisture}

A total of $3.0 \mathrm{~g}$ of endocarp samples were weighed in glass plates, previously dehumidified in an oven at $105^{\circ} \mathrm{C}$, and kept in an oven (TE-394/2; Tecnal, Ourinhos, SP, Brazil) at $105^{\circ} \mathrm{C}$ until constant weight. The result was calculated gravimetrically according to Adolph Lutz Institute (IAL, 2008).

\section{Ashes}

Ash content was determined, according to IAL (2008), from $0.5 \mathrm{~g}$ of endocarp samples contained in porcelain crucible, previously calcined in muffle at $550{ }^{\circ} \mathrm{C}$. The samples were previously carbonized and then incinerated in muffle at $550{ }^{\circ} \mathrm{C}$. After complete incineration, the crucibles containing the samples were cooled in a desiccator and weighed.

\section{Proteins}

Protein content was quantified by the Kjeldahl method, according to IAL (2008), adding $0.5 \mathrm{~g}$ of sample, $600 \mathrm{mg}$ of potassium sulphate, $10 \mathrm{~mL}$ of concentrated sulfuric acid and $300 \mathrm{mg}$ of copper sulphate in a glass tube, followed by digestion at $350{ }^{\circ} \mathrm{C}$. Subsequently, $50 \mathrm{ml}$ of $50 \%$ sodium hydroxide was added to the tubes and the mixture was distilled in nitrogen distiller (Tecnal, Ourinhos, SP, Brazil). The distillate was collected in a $250 \mathrm{~mL}$ conical flask containing $15 \mathrm{~mL}$ of saturated boric acid solution and methyl red indicator solution $(0.1 \%)$. Subsequently, the distillate was titrated with $0.02 \mathrm{~N}$ of hydrochloric acid.

\section{Lipids}

Endocarp samples $(1.0 \mathrm{~g})$ were transferred to qualitative filter paper, with a porosity of 12.5 $\mu \mathrm{m}$, and placed in Soxhlet extractor. Lipids were extracted with ethyl ether approximately for $8 \mathrm{~h}$ and collected in $250 \mathrm{~mL}$ flat bottom dehumidified flasks. After extraction, the flasks were placed in the oven at $105^{\circ} \mathrm{C}$ for solvent evaporation and lipids quantification (IAL, 2008).

\section{Crude fiber}

Crude fiber content was determined with the addition of $0.5 \mathrm{~g}$ of the sample, $17.5 \mathrm{~mL}$ of $70 \%$ acetic acid and $0.5 \mathrm{~g}$ of trichloroacetic acid in test tubes, which were digested at $110^{\circ} \mathrm{C}$ for $30 \mathrm{~min}$. Subsequently, the material was filtered using pre-sintered filters, containing glass wool, washed with distilled water $\left(95 \pm 2{ }^{\circ} \mathrm{C}\right)$, until $\mathrm{pH}$ neutrality and oven dried at $105^{\circ} \mathrm{C}$ (Kamer \& Ginkel, 1952).

\section{Starch and total soluble sugars (TSS)}

Starch and total soluble sugars were determined according to the methodology described by Mccready et al. (1950). The quantification was performed with anthrone $0.1 \%$ in sulfuric acid addition and absorbance determination in the spectrophotometer. 


\section{Cellulose, hemicellulose, and lignin}

Cellulose, hemicellulose and lignin contents were quantified by neutral detergent fiber (NDF) and acid detergent fiber (FDA) methods described by Van Soest (1963), Van Soest (1964) and Van Soest (1968).

\section{Pre-treatment of buriti endocarp}

Whole buriti endocarps, dried and ground, were pre-treated with dilute sulfuric acid followed by hydrolysis with alkali to remove fractions of hemicellulose and lignin, respectively. The experiments were executed in three replicates.

\section{Treatment with dilute sulfuric acid}

Determination of optimal conditions for acid pre-treatment of the biomass was accomplished through the use of a Rotational Central Composite Design (RCCD) that evaluated the influence of reaction time; $20 \mathrm{~min}(-1)$ and $60 \mathrm{~min}(-1)$, solid-liquid (S/L) ratio; $10 \%(-1)$ and $20 \%(+1)$, and concentration of sulfuric acid $\left(\mathrm{H}_{2} \mathrm{SO}_{4}\right) ; 2 \%(-1)$ and $7 \%(+1)$, on the removal of hemicellulose contained in the buriti endocarp. In each test, carried out in a glass tube $(30 \times 2.5 \mathrm{~cm}), 1 \mathrm{~g}$ of dry sample was added with the solution of $\mathrm{H}_{2} \mathrm{SO}_{4}$ in the pre-defined concentration and proportion for each of the 18 tests generated by the factorial matrix $2^{3}$, containing four central points and six axial points. The tests were performed in an autoclave at a fixed temperature of $120^{\circ} \mathrm{C}$. Treatment conditions and parameters were based on Corbin et al. (2015) work.

\section{Determination of sugars removed by acid pre-treatment}

Quantification of glucose released after acid hydrolysis was determined by the enzymaticcolorimetric method described by Lloyd \& Whelan (1969). Quantification of reducing sugars (RS) in the acid hydrolyzate was carried out using the dinitrosalicylic acid method described by Miller (1959). The decomposition of hemicellulose was expressed in grams of sugar released per $100 \mathrm{~g}$ of biomass.

\section{Pre-treatment with sodium hydroxide}

Optimization of lignin removal from buriti endocarps was performed by $2^{2}$ RCCD factorial experiments, which investigated the influence of process temperature; $30^{\circ} \mathrm{C}(-1)$ and $80{ }^{\circ} \mathrm{C}(+1)$, and concentration of sodium hydroxide $(\mathrm{NaOH}) ; 2 \%(-1)$ and $12 \%$ $(+1)$, in addition to four central points and four axial points. In each test, carried out in the glass tube $(30 \times 2.5 \mathrm{~cm}), 1 \mathrm{~g}$ of dry sample, sodium hydroxide solution at a solid-liquid ratio of $10 \%$, were added and then incubated in a water bath for the period of 12, 24, 36 and $48 \mathrm{~h}$. Lignin removal was estimated by total phenolic compounds dosage using gallic acid as standard, according to Singleton \& Rossi (1965).

\section{Enzymatic saccharification of pretreated endocarp}

For the saccharification process optimization, an RCCD with three factors was performed. Analyzing the effect of S/L ratio; $5 \%(-1)$ and 15\% (+1), time; $6 \mathrm{~h}(-1)$ and $24 \mathrm{~h}(+1)$, and enzyme concentration (Celluclast; Novozymes, Bagsværd. Denmark); $20 \mu \mathrm{L} \mathrm{g}^{-1}(-1)$ and $100 \mu \mathrm{L} \mathrm{g}^{-1}(+1)$, with four central points and six axial points. In each condition described by the RCCD planning, the mass of $1 \mathrm{~g}$ of pre-treated endocarp was used in a $50 \mathrm{~mL}$ conical 


\begin{tabular}{lc} 
Table $1 \quad$ Physical characterization of in natura buriti fruit. & \\
Parameter & Average \\
\hline Pulp mass (g) & $9.26 \pm 2.94$ \\
Epicarp mass (g) & $9.40 \pm 2.04$ \\
Endocarp mass (g) & $9.72 \pm 3.00$ \\
Peduncle mass (g) & $0.83 \pm 0.26$ \\
Seed mass (g) & $6.01 \pm 2.16$ \\
Transversal diameter (mm) & $38.75 \pm 3.76$ \\
Longitudinal diameter (mm) & $48.68 \pm 2.94$ \\
\hline
\end{tabular}

flask, followed by the addition of $50 \mathrm{mM}$ sodium bicarbonate buffer ( $\mathrm{pH}$ 5.0) and enzyme volume according to experimental planning. Pre-treated endocarp was rinsed with distillate water and dried before utilization. The tests were incubated at $50{ }^{\circ} \mathrm{C}$ with agitation of 100 $\mathrm{rpm}$. At the end of each reaction, the concentrations of glucose and reducing sugars (RS) were determined in the soluble fraction of the hydrolyzate. The digestion of cellulose was expressed in grams of glucose released per $100 \mathrm{~g}$ of biomass.

\section{Alcoholic fermentation of the enzymatic hydrolyzate}

Fermentation of the optimized enzymatic hydrolyzate was carried out in $250 \mathrm{~mL}$ conical flasks coupled to fermentometers, a glass system that allows carbon dioxide $\left(\mathrm{CO}_{2}\right)$ release and prevents the entry of external air, at room temperature $\left(25 \pm 2{ }^{\circ} \mathrm{C}\right)$. Dehydrated commercial baker's yeast (Fleischmann ${ }^{\circledR}$ ) of the Saccharomyces cerevisiae species was used as a fermentation agent in the ratio of $1 \%(\mathrm{w} / \mathrm{v})$ to the must volume. No nutrient supplementation was applied. The fermentative process was monitored gravimetrically for $\mathrm{CO}_{2}$ release. The measurement of the mass of gas released was used to estimate the ethanol production and fermentable sugars consumption at every two hours until the end of the fermentation. Ethanol concentration was quantified by the potassium dichromate method (Isarankura-Na-Ayudhya et al., 2007). Glucose and reducing sugars (RS) concentrations were also determined.

\section{Statistical analysis}

Modeling, graphing and analysis of the results obtained with the rotational central composite designs were performed using tools available in Statistica 8.0 software (Statsoft Inc., Tulsa). ANOVA with $p<0.05$ level was stipulated as the statistical parameter of significance.

\section{RESULTS}

Physical characterizations of fresh buriti fruits are displayed in Table 1, the values are presented in percentage averages followed by their standard deviations. Integral fruits presented an average mass of $38.33 \pm 9.06 \mathrm{~g}$, the transversal diameter of $38.75 \pm 3.76 \mathrm{~mm}$ and longitudinal diameter of $48.68 \pm 2.94 \mathrm{~mm}$ (Table 1). The endocarp mass represented, on average, $25.3 \%$ of the whole fruit. 


\begin{tabular}{lc}
\hline $\begin{array}{l}\text { Table } 2 \text { Chemical characterization of buriti fruit endocarp. Percentage averages followed by their stan- } \\
\text { dard deviations. }\end{array}$ & $\begin{array}{c}\text { Endocarp } \\
\text { (Seed shell) }\end{array}$ \\
Composition & $9.54 \pm 0.19$ \\
\hline Moisture (\%) & $4.46 \pm 0.08$ \\
Ash (\%) & $4.39 \pm 0.37$ \\
Lipids (\%) & $3.62 \pm 0.08$ \\
Total Proteins (\%) & $26.37 \pm 0.44$ \\
Crude Fiber (\%) & $4.49 \pm 0.13$ \\
TSS (\%) & $6.80 \pm 0.18$ \\
Starch (\%) & $22.15 \pm 2.43$ \\
Cellulose (\%) & $10.73 \pm 0.79$ \\
Hemicellulose (\%) & $11.79 \pm 0.30$ \\
\hline
\end{tabular}

Notes.

TSS, Total Soluble Sugars.

Table 2 shows the Buriti fruit endocarp chemical composition. It is possible to observe a crude fiber content greater than $26 \%$ and four main sugar sources that could be converted to bioethanol; starch, cellulose, hemicellulose and soluble sugars. Total carbohydrates portion corresponded to $44.2 \%$ of the biomass (Table 2). Cellulose was the main polymer on the endocarp composition, with a content of $22.15 \%$, hemicellulose fraction corresponded to $10.73 \%$, and lignin fraction was $11.79 \%$. Moisture, lipids, ash and protein contents are also listed in Table 2.

In this study, buriti endocarp was subjected to a sequence of acid and alkali treatments with the purpose of exposing the cellulose polymers to the enzymatic hydrolysis to obtain monomers of hexoses for their subsequent anaerobic fermentation by $S$. cerevisiae yeast.

The quantities of reducing sugars and glucose removed per $100 \mathrm{~g}$ of endocarp subjected to acid pretreatment under the experimental design conditions are shown in Table 3. There was the greater release of reducing sugars in the condition of test $10(15 \% \mathrm{~S} / \mathrm{L}$ ratio, $8.04 \%$ $\mathrm{H}_{2} \mathrm{SO}, 40 \mathrm{~min}$ ). In this point, $8.75 \mathrm{~g}$ of reducing sugars per $100 \mathrm{~g}$ of biomass was removed. On the other hand, in the condition of test $5\left(10 \% \mathrm{~S} / \mathrm{L}\right.$ ratio, $\left.7 \% \mathrm{H}_{2} \mathrm{SO}, 20 \mathrm{~min}\right), 8.02 \mathrm{~g}$ of reducing sugars per $100 \mathrm{~g}$ of biomass were removed, $9 \%$ less than under test condition 10 . Test 5 was then chosen as the optimal condition for the preparative test for using less acid concentration, presenting great RS release (hemicellulose removal) and half the reaction time of test 10 .

The concentration of $\mathrm{H}_{2} \mathrm{SO}_{4}$ had a significant and positive linear effect $(p<0.05)$ on hemicellulose removal and the interaction of $\mathrm{H}_{2} \mathrm{SO}_{4}$ concentration over time $(p<0.05)$ had a negative effect. Negative quadratic individual effects of $\mathrm{H}_{2} \mathrm{SO}_{4}$ and $\mathrm{S} / \mathrm{L}$ ratio were also observed, however, with $p$ values of 0.114 and 0.102 , respectively.

The combined effects of $\mathrm{H}_{2} \mathrm{SO}_{4}$ concentration with the $\mathrm{S} / \mathrm{L}$ ratio factors and $\mathrm{H}_{2} \mathrm{SO}_{4}$ concentration over time on the removal of the hemicellulosic portion from the buriti endocarp are presented as response surface curves in Fig. 2; the coefficient of determination $\left(R^{2}\right)$ was 0.81 . Not coincidentally, the areas under the response surface curves (Fig. 2) 
Table 3 Rotational central composite design for the acid pretreatment of buriti endocarp ( 1 atm, $120^{\circ} \mathrm{C}$ ) with its respective response factors.

\begin{tabular}{|c|c|c|c|c|c|}
\hline \multirow[t]{2}{*}{ Test } & \multicolumn{3}{|c|}{ Independent variables } & \multicolumn{2}{|c|}{ Response factors } \\
\hline & $\mathrm{S} / \mathrm{L}$ ratio $(\%)$ & $\mathrm{H}_{2} \mathrm{SO}_{4}(\%)$ & Time (min.) & Glucose (\%) & RS (\%) \\
\hline 1 & 10 & 2.00 & 20.0 & 0.92 & 2.22 \\
\hline 2 & 20 & 2.00 & 20.0 & 0.38 & 0.85 \\
\hline 3 & 10 & 2.00 & 60.0 & 1.52 & 5.63 \\
\hline 4 & 20 & 2.00 & 60.0 & 0.70 & 2.55 \\
\hline 5 & 10 & 7.00 & 20.0 & 1.84 & 8.02 \\
\hline 6 & 20 & 7.00 & 20.0 & 1.05 & 5.01 \\
\hline 7 & 10 & 7.00 & 60.0 & 0.79 & 4.26 \\
\hline 8 & 20 & 7.00 & 60.0 & 0.35 & 2.52 \\
\hline 9 & 15 & 0.96 & 40.0 & 0.13 & 0.90 \\
\hline 10 & 15 & 8.04 & 40.0 & 2.10 & 8.75 \\
\hline 11 & 15 & 4.50 & 11.7 & 0.57 & 3.21 \\
\hline 12 & 15 & 4.50 & 68.3 & 1.68 & 7.30 \\
\hline 13 & 7 & 4.50 & 40.0 & 1.21 & 5.10 \\
\hline 14 & 22 & 4.50 & 40.0 & 0.92 & 4.70 \\
\hline 15 & 15 & 4.50 & 40.0 & 1.46 & 6.65 \\
\hline 16 & 15 & 4.50 & 40.0 & 1.11 & 5.90 \\
\hline 17 & 15 & 4.50 & 40.0 & 1.37 & 6.71 \\
\hline 18 & 15 & 4.50 & 40.0 & 1.24 & 6.88 \\
\hline
\end{tabular}

Notes.

S/L, Solid-liquid ratio; RS, reducing sugars.

representing the regions with the highest hemicellulose removal refer to the combination of factors indicated by the conditions of test 5 (Table 3).

Characterization of the lignocellulosic fraction of buriti endocarp recovered after acid pretreatment (51.4\% mass recovery), using the optimum condition defined, indicated changes in the lignocellulosic content. Cellulose, hemicellulose and lignin fractions found were, respectively; $43.07 \pm 0.47 \%, 1.29 \pm 0.04 \%$ and $24.50 \pm 0.38 \%$. It is possible to see the great impact of the treatment on hemicellulose removal, which showed an $88.26 \%$ reduction on content, compared to the raw endocarps, followed by concomitant concentration of the cellulose and lignin fractions, polymers that were not removed by acid action.

The results for the RCCD of lignin removal from the acid pre-treated buriti endocarps are presented in Table 4 for times of 12, 24, 36 and $48 \mathrm{~h}$. In all caustic hydrolysis times evaluated, the alkali used $(\mathrm{NaOH})$ had a positive and significant effect $(p<0.05)$ on lignin removal. The temperature also had a positive and significant effect $(p<0.05)$ on lignin removal at all evaluated times. The regression analysis squared correlation coefficients $\left(\mathrm{R}^{2}\right)$ were $0.97,0.83,0.94$ and 0.93 , for the times of $12,24,36$ and $48 \mathrm{~h}$, respectively.

As can be seen in Table 4, the reaction time of $48 \mathrm{~h}$ was the most favorable for lignin removal. The polynomial fit that describes the percentage of lignin removal, expressed in the form of phenolic compounds, as a function of the temperature and $\mathrm{NaOH}$ concentration 

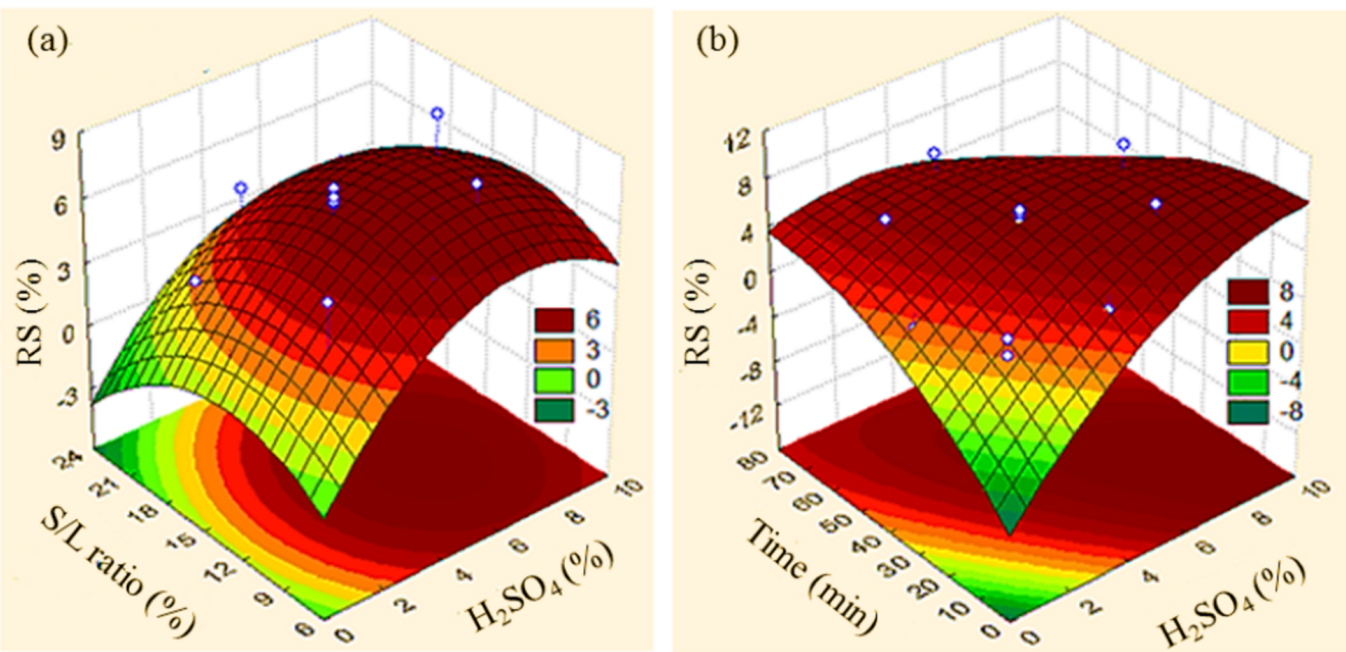

Figure 2 Response surface graphs. Percentage of reducing sugars (RS) removed in the acid hydrolysis of the buriti endocarp as a function of the combined effects of the (A) concentration of $\mathrm{H}_{2} \mathrm{SO}_{4}$ with solidliquid ratio (S/L), and (B) time with $\mathrm{H}_{2} \mathrm{SO}_{4}$ concentration.

Full-size DOI: 10.7717/peerj.5275/fig-2

Table 4 Rotational central composite design for the alkaline pretreatment of the buriti endocarp remaining from the acid pretreatment with its respective response factor in the times of $12 \mathrm{~h}, 24 \mathrm{~h}, 36 \mathrm{~h}$ and $48 \mathrm{~h}$.

\begin{tabular}{|c|c|c|c|c|c|c|}
\hline \multirow[t]{2}{*}{ Test } & \multicolumn{2}{|c|}{ Independent variables } & \multicolumn{4}{|c|}{ Total phenolic compounds } \\
\hline & $\mathrm{NaOH}(\%)$ & Temperature $\left({ }^{\circ} \mathrm{C}\right)$ & $12 \mathrm{~h}(\%)$ & $24 \mathrm{~h}(\%)$ & $36 \mathrm{~h}(\%)$ & $48 \mathrm{~h}(\%)$ \\
\hline 1 & 2.00 & 30.00 & 0.86 & 1.56 & 1.93 & 2.33 \\
\hline 2 & 2.00 & 80.00 & 1.73 & 2.31 & 3.75 & 4.45 \\
\hline 3 & 12.00 & 30.00 & 1.88 & 1.96 & 2.33 & 3.28 \\
\hline 4 & 12.00 & 80.00 & 3.28 & 5.69 & 8.40 & 9.64 \\
\hline 5 & 0.95 & 55.00 & 0.48 & 1.06 & 1.23 & 1.85 \\
\hline 6 & 13.05 & 55.00 & 2.43 & 2.96 & 4.65 & 4.84 \\
\hline 7 & 7.00 & 24.75 & 1.11 & 1.43 & 2.06 & 3.75 \\
\hline 8 & 7.00 & 85.25 & 3.09 & 3.92 & 5.69 & 6.55 \\
\hline 9 & 7.00 & 55.00 & 1.77 & 2.54 & 4.87 & 5.28 \\
\hline 10 & 7.00 & 55.00 & 1.83 & 2.57 & 4.91 & 5.15 \\
\hline 11 & 7.00 & 55.00 & 1.81 & 2.49 & 4.82 & 5.25 \\
\hline 12 & 7.00 & 55.00 & 1.75 & 2.43 & 4.89 & 5.23 \\
\hline
\end{tabular}

in the time of maximum lignin hydrolysis (48h) is represented by Eq. (1).

$\mathrm{L}=5.10+2.82 \mathrm{C}-1.75 \mathrm{C}^{2}+3.43 \mathrm{~T}+0.71 \mathrm{~T}^{2}+2.12 \mathrm{CT}$

Where:

$L=$ Total phenolic compounds (\%);

$C=\mathrm{NaOH}$ concentration $(\%)(\mathrm{m} / \mathrm{v})$;

$T=$ Temperature $\left({ }^{\circ} \mathrm{C}\right)$. 


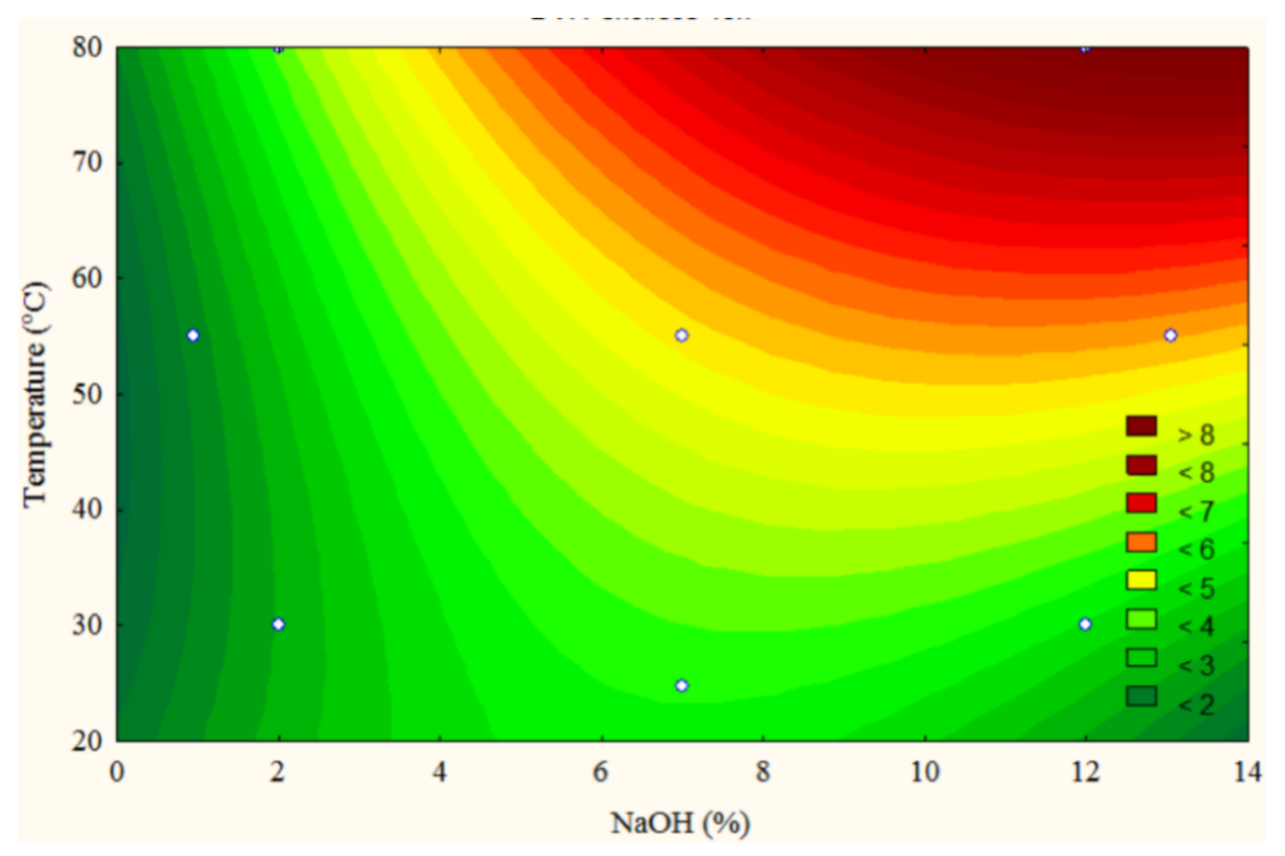

Figure 3 Projection of the adjusted response surface curve for the rotational central composite design in the time of $48 \mathrm{~h}$.

Full-size DOI: 10.7717/peerj.5275/fig-3

The graph of the projection of response surface to the time of $48 \mathrm{~h}$ is seen in Fig. 3. The region where the maximum release of phenolic compounds can be observed is represented by a temperature higher than $80{ }^{\circ} \mathrm{C}$ and $\mathrm{NaOH}$ concentration between 10 and $14 \%$. The highest release of phenolic compounds was observed in the reaction medium with $12 \%$ $\mathrm{NaOH}$ and temperature of $80^{\circ} \mathrm{C}$ (test 4 , Table 4 ). This condition was adopted for the preparatory pretreatment of the biomass previously submitted to acid pretreatment.

Characterization of the lignocellulosic fraction of the biomass recovered after the alkaline pre-treatment (49.5\% mass recovery) showed that there was a $64 \%$ reduction in lignin concentration when compared to the raw biomass (untreated) and $83 \%$ when compared to the biomass after the acid pretreatment. The contents of cellulose, hemicellulose, and lignin in the endocarp after caustic hydrolysis were; $88.54 \pm 0.38 \%, 2.73 \pm 0.16 \%$ and $4.20 \pm 0.28 \%$, correspondingly.

The experiments to optimize the saccharification process of cellulose contained in the pretreated biomass are displayed in Table 5. The condition of the test that presented the greatest release of glucose (in average $77.08 \%$ ) or reducing sugars (in average $80.65 \%$ ) was described by the central points, tests $15,16,17$ and $18\left(60.00 \mu \mathrm{L} \mathrm{g}^{-1}\right.$ cellulase, $10.00 \% \mathrm{~S} / \mathrm{L}$ ratio and $15.0 \mathrm{~h}$ ).

All quadratic effects were negative and significant $(p<0.05)$, indicating that there were maximum points in the hydrolytic phenomenon. The release profiles of glucose and reducing sugars under the conditions of the RCCD can be seen in Fig. 4, as well as the optimal condition highlighted for saccharification of the biomass. The model obtained by the experimental design had a regression coefficient $\left(R^{2}\right)$ of $84.15 \%$ for the glucose release 
Table 5 Rotational central composite design used for the enzymatic saccharification of the buriti endocarp sequentially pretreated with acid and alkali and their respective response factors.

\begin{tabular}{llllll} 
Test & Cellulase $\left(\mu \mathbf{L ~ g}^{-1}\right)$ & S/L ratio (\%) & Time $(\mathbf{h})$ & Glucose (\%) & RS (\%) \\
\hline 1 & 20.00 & 5.00 & 6.0 & 11.36 & 14.09 \\
2 & 20.00 & 5.00 & 24.0 & 16.60 & 16.81 \\
3 & 20.00 & 15.00 & 6.0 & 17.83 & 16.23 \\
4 & 20.00 & 15.00 & 24.0 & 51.39 & 56.06 \\
5 & 100.00 & 5.00 & 6.0 & 23.60 & 21.13 \\
6 & 100.00 & 5.00 & 24.0 & 33.21 & 31.12 \\
7 & 100.00 & 15.00 & 6.0 & 46.67 & 46.95 \\
8 & 100.00 & 15.00 & 24.0 & 61.20 & 59.24 \\
9 & 3.43 & 10.00 & 15.0 & 6.99 & 5.67 \\
10 & 116.57 & 10.00 & 15.0 & 53.49 & 58.72 \\
11 & 60.00 & 2.93 & 15.0 & 20.97 & 19.69 \\
12 & 60.00 & 17.07 & 15.0 & 31.46 & 32.91 \\
13 & 60.00 & 10.00 & 2.3 & 10.48 & 15.20 \\
14 & 60.00 & 10.00 & 27.7 & 63.63 & 61.77 \\
15 & 60.00 & 10.00 & 15.0 & 76.92 & 80.59 \\
16 & 60.00 & 10.00 & 15.0 & 76.04 & 79.99 \\
17 & 60.00 & 10.00 & 15.0 & 78.67 & 80.35 \\
18 & 60.00 & 10.00 & 15.0 & 76.04 & 81.68 \\
\hline
\end{tabular}

and $84.42 \%$ for the release of reducing sugars. The optimum condition indicated by the response surface methodology (Fig. 4) showed the combined use of $74.50 \mu \mathrm{L}$ of Cellulase $\mathrm{g}^{-1}$ of biomass, $11.30 \%$ for the $\mathrm{S} / \mathrm{L}$ ratio and $19.40 \mathrm{~h}$ of reaction time.

After applying the optimum saccharification conditions in a preparative test with the pre-treated buriti endocarp, the hydrolyzate obtained contained $129.68 \pm 0.72 \mathrm{~g} \mathrm{~L}^{-1}$ of reducing sugars and $110.14 \pm 0.63 \mathrm{~g} \mathrm{~L}^{-1}$ of glucose, displaying and hydrolytic efficiency of $86.16 \%$.

The fermentation process was monitored gravimetrically by the evolution of $\mathrm{CO}_{2}$ and the equivalent values of glucose consumed and ethanol produced was calculated during $18 \mathrm{~h}$ of reaction (Fig. 5). At $16 \mathrm{~h}$ the fermentation had been completed since no change in the mass of the fermentative system was observed.

Once the fermentation was complete, the system was opened and the glucose, reducing sugars and ethanol contents were determined analytically. Thus, $43.16 \mathrm{~g} \mathrm{~L}^{-1}$ of ethanol was produced, with a fermentative efficiency (ethanol yield) of $77 \%$ or $0.33 \mathrm{~g} \mathrm{EtOH} \mathrm{g}$ $\mathrm{RS}^{-1}$. The concentrations of glucose and RS at the end of fermentation were, respectively; $25.10 \mathrm{~g} \mathrm{~L}^{-1}$ and $37.59 \mathrm{~g} \mathrm{~L}^{-1}$.

\section{DISCUSSION}

Palm trees endocarp composition data are scarce in literature, what highlights the relevance of Table 2 information. Comparatively, Saka et al. (2008) found a similar cellulose content (20.5\%) on Elaeis guineensis endocarp to that found for Mauritia flexuosa endocarp in the present study, nonetheless the hemicellulose content reported by the cited authors 


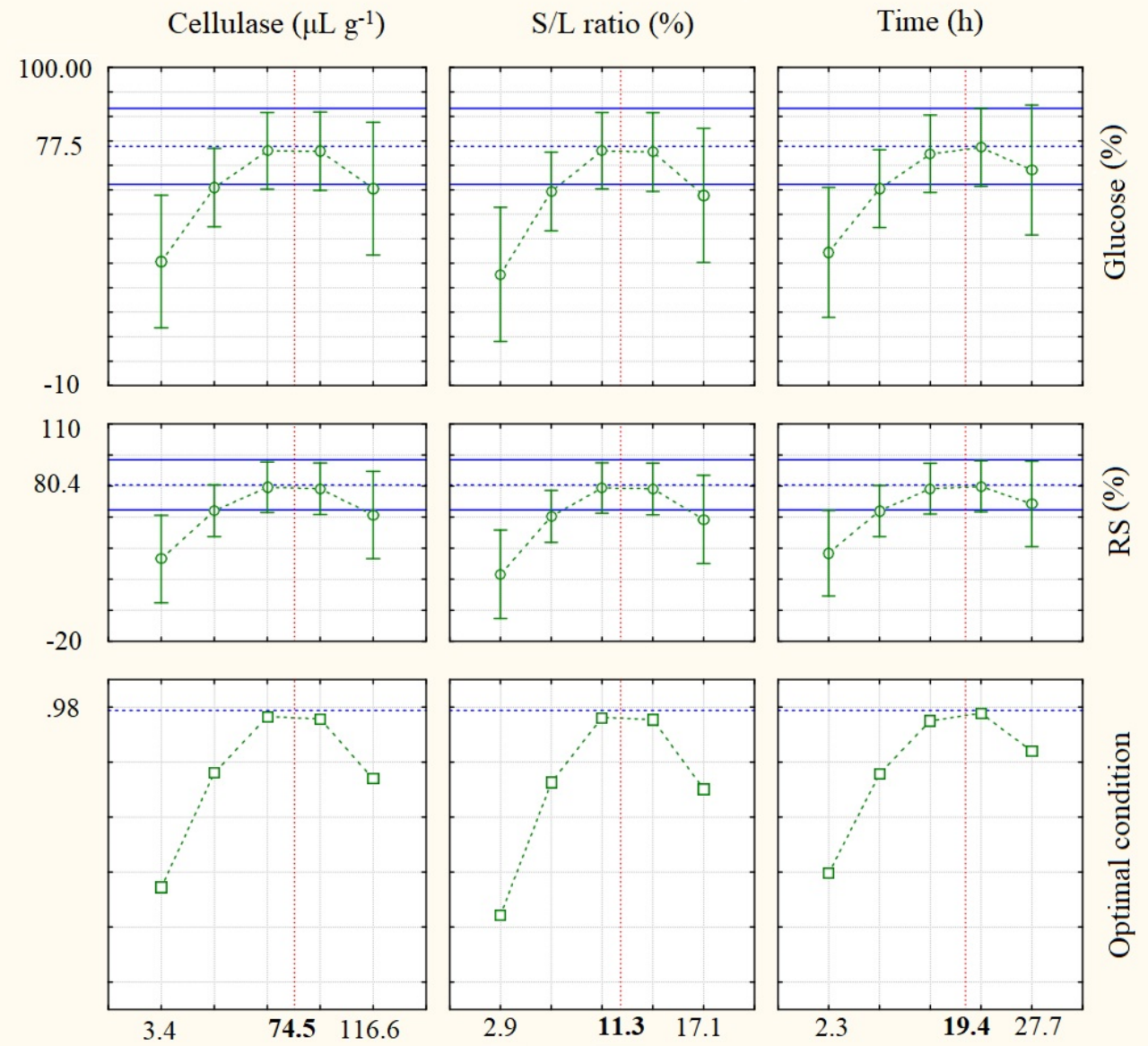

Figure 4 Profile of predicted and desirable glucose and reducing sugar (RS) values. ( $y$-axes) for cellulase concentration, $\mathrm{S} / \mathrm{L}$ ratio and process time factors ( $x$-axes) used in saccharification of the cellulose contained in the pre-treated buriti endocarp.

Full-size DOI: 10.7717/peerj.5275/fig-4

was two times higher $(22.3 \%)$ than that described in this paper. Is important to mention that chemical composition of a biomass is mainly determined by its evolutionary history and varies significantly with the species (Mendu et al., 2011; Dardick \& Callahan, 2014). The lignocellulosic fraction also varies depending on the stage of development and the anatomical part of the plant (Handley, Pharr \& McFeeters, 1983; Dardick \& Callahan, 2014).

Regarding the dilute acid treatment described in the present study, the concentration of $\mathrm{H}_{2} \mathrm{SO}_{4}$ had a significant positive linear effect on hemicellulose removal. A negative effect on the interaction of $\mathrm{H}_{2} \mathrm{SO}_{4}$ concentration over time was also noted. Probably, such phenomenon is due to dehydration of glucose to hydroxymethylfurfural promoted by the acid at the longest reaction times (Deshavath et al., 2017; Woo et al., 2015). In addition, it is also probable that the glucose found in the hydrolyzate was the product of the hydrolysis of starch present in the endocarp since $\beta$ 1,4 glycosidic bonds between glucose residues of cellulose are recalcitrant to the action of dilute acids. 


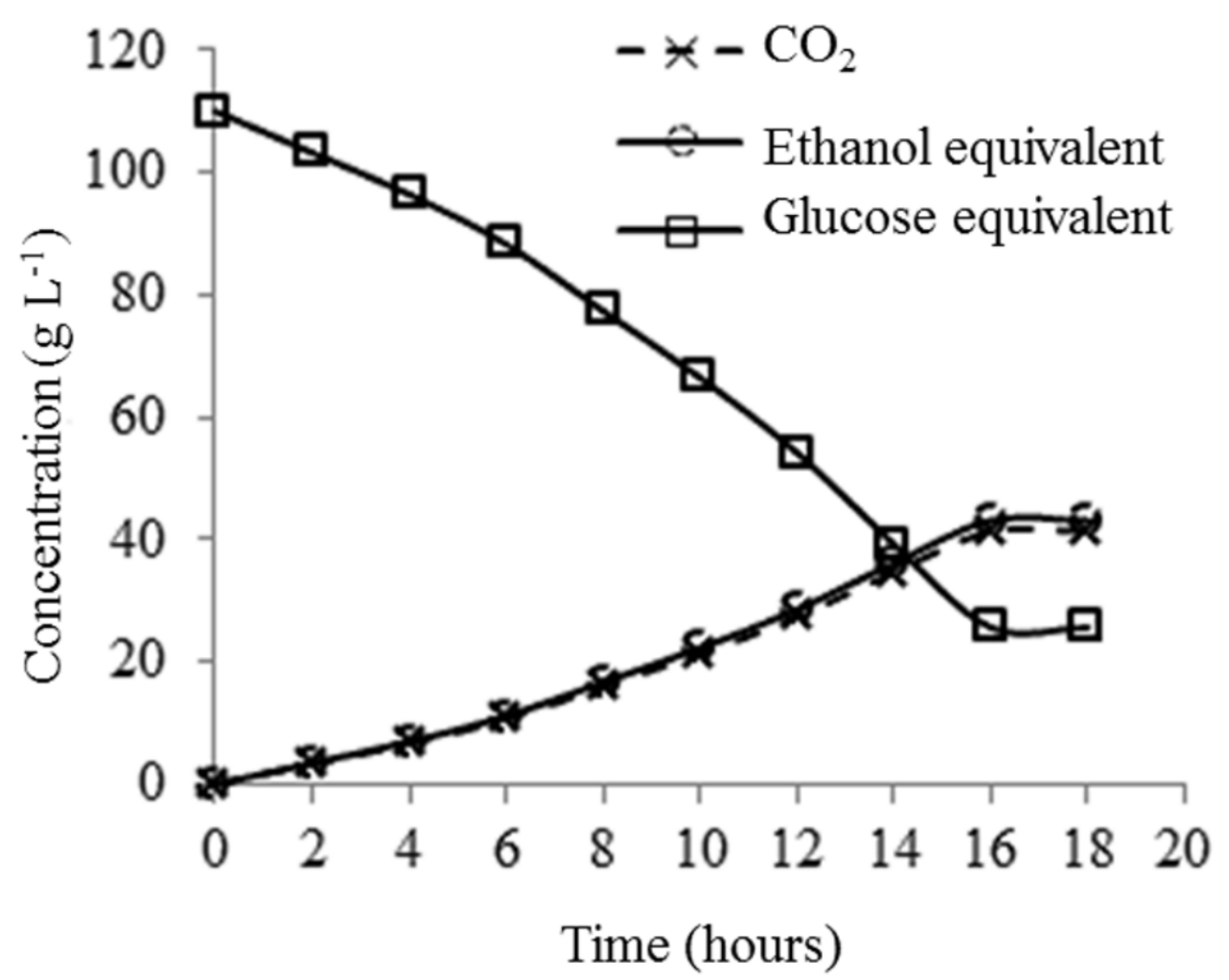

Figure 5 Progress of the alcoholic fermentation of the enzymatic hydrolyzate of the pre-treated buriti endocarp, conducted in anaerobiosis with Saccharomyces cerevisiae yeast.

Full-size DOI: 10.7717/peerj.5275/fig-5

In their studies of dilute acid pre-treatment $\left(1 \mathrm{~h}, 121^{\circ} \mathrm{C}, 0.5 \mathrm{M} \mathrm{H}_{2} \mathrm{SO}_{4}\right)$ of red and white grape marcs, Corbin et al. (2015) achieved $58 \%$ of total carbohydrates liberation from the red marc and 84\% from the white marc. Gonzales, Sivagurunathan \& Kim (2016) reported a hemicellulose recovery of $57.4 \%$ from empty palm fruit bunch $\left(60 \mathrm{~min}, 121^{\circ} \mathrm{C}, 5 \%\right.$ $\mathrm{H}_{2} \mathrm{SO}_{4}$ ). Zhang et al. (2011), in turn, reported $74.5 \%$ release of the total hemicellulose in his pretreatment assessments of cattails (Typha species) $\left(15 \mathrm{~min}, 180{ }^{\circ} \mathrm{C}, 1 \% \mathrm{H}_{2} \mathrm{SO}_{4}\right.$ ), demonstrating inferior performances than what was accomplished in this paper.

After caustic hydrolysis, the buriti fruit endocarp, previously treated with dilute acid, showed a drastic reduction of lignin content compared to the raw biomass. Barliante et al. (2015) published a lignin removal of $47.3 \%$ from oil palm fronds with alkaline hydrolysis as the sole treatment in their best conditions set $\left(30 \mathrm{~min}, 150{ }^{\circ} \mathrm{C}, 10 \% \mathrm{NaOH}\right)$. Chieng et al. (2017) reported $78.7 \%$ decrease in lignin content of oil palm mesocarp fiber, after sequential alkaline $\left(3 \mathrm{~h}, 80{ }^{\circ} \mathrm{C}, 4 \% \mathrm{NaOH}\right)$ and dilute acid $\left(45 \mathrm{~min}, 45^{\circ} \mathrm{C}, 65 \% \mathrm{H}_{2} \mathrm{SO}_{4}\right.$ ) treatments. Although the last authors achieved a hydrolysis performance less efficient than what is described in the present paper, they attained a similar final lignin fraction in their biomass than that revealed in the present study.

Also applying sequential alkaline and diluted acid hydrolysis, but using calcium hydroxide and peracetic acid, Azelee et al. (2014) reported 59.25\% lignin removal (1 g L ${ }^{-1}$ 
$\mathrm{Ca}(\mathrm{OH})_{2}$, S-L ratio of $1: 8,50{ }^{\circ} \mathrm{C}$ for $1.5 \mathrm{~h}$; followed by $20 \%$ peracetic acid pretreatment at $75^{\circ} \mathrm{C}$ for $2 \mathrm{~h}$ ) in their studies of ethanol production from kenaf (Hibiscus cannabinus).

Enzymatic saccharification performed revealed negative quadratic effects indicating maximum points of hydrolytic efficiency, probably due to the exhaustion of the susceptible substrate and/or limitation in mass transfer, which can largely affect the enzymatic attack. The yield of glucose in the optimum condition $\left(60.00 \mu \mathrm{L} \mathrm{g}^{-1}\right.$ cellulase, $10.00 \% \mathrm{~S} / \mathrm{L}$ ratio and $15.0 \mathrm{~h}$ ) is aligned with some author's suggestion for process sustainability, in terms of costs. They indicate that the presence of 10 to $20 \%$ of the non-hydrolyzed substrate in the reaction medium might be a more effective strategy (Arantes \& Saddler, 2011; Shen \& Agblevor, 2008).

Asada et al. (2015) reported a saccharification slightly higher than what is seen in this paper, with a glucose yield of $89 \%$ for pre-treated Beechwood using enzymatic hydrolysis (initial substrate concentration of $2 \%, 0.1 \mathrm{~g}$ of enzyme per $1 \mathrm{~g}$ of the substrate, $120,50{ }^{\circ} \mathrm{C}$ ). Alrumman (2016) described an enzymatic saccharification yield of $71.03 \%$ with Geobacillus stearothermophilus palm waste ( $4 \% \mathrm{~S} / \mathrm{L}$ ratio, $30 \mathrm{FPU} / \mathrm{g}$ enzyme, $5.0 \mathrm{pH}, 50{ }^{\circ} \mathrm{C}, 24 \mathrm{~h}$ ).

It is possible to observe in the fermentation experiment with Saccharomyces cerevisiae that $28.99 \%$ of the reducing sugars present in the medium were not consumed. The pretreatment processes of lignocellulosic biomasses employed in this work are widely used strategies; however, they have the disadvantage of generating toxic compounds to fermenting organisms, such as phenolic compounds, guaiacol, levulinic acid, furfural and 5-hydroxymethylfurfural (Varanasi et al., 2013; Liu et al., 2016). Although the pre-treated endocarp was rinsed with distillate water before enzymatic scarification, Zhang et al. (2010) indicate that this method is not efficient for total removal of toxic compounds impregnated in the biomass. Thereby, the presence of such substances may have inhibited the activity of $S$. cerevisiae, making it impossible to deplete the substrate offered.

Kamoldeen et al. (2017), Koti et al. (2016) and Jing-Ping et al. (2011) reported similar ethanol yields in fermentations of oil palm empty fruit bunches with Saccharomyces cerevisiae ATCC $24858\left(0.33 \mathrm{~g} \mathrm{~g}^{-1}\right)$, wheat straw with Pichia stipitis PSEB5 $\left(0.34 \mathrm{~g} \mathrm{~g}^{-1}\right)$ and corncob using Candida shehatae ACCC 20335 ( $\left.0.31 \mathrm{~g} \mathrm{~g}^{-1}\right)$, respectively. However, the ethanol yield ( $\left.\mathrm{Y}_{\mathrm{P} / \mathrm{S}}\right)$ achieved by Ko et al. (2016) using rice straw hydrolysate reached 0.46 $\mathrm{g} \mathrm{g}^{-1}$, a value significantly higher than what is detected in this study.

\section{CONCLUSION}

Buriti fruit endocarps were successfully converted to bioethanol by Saccharomyces cerevisiae. The sequential use of diluted acid $\left(10 \% \mathrm{~S} / \mathrm{L}\right.$ ratio, $\left.120{ }^{\circ} \mathrm{C}, 7 \% \mathrm{H}_{2} \mathrm{SO}, 20 \mathrm{~min}\right)$ and alkaline $\left(10 \% \mathrm{~S} / \mathrm{L}\right.$ ratio, $\left.80^{\circ} \mathrm{C}, 12 \% \mathrm{NaOH}, 48 \mathrm{~h}\right)$ hydrolysis, under optimized conditions, contributed significantly to the reduction of hemicellulose and lignin contents in the pre-treated biomass. These treatments reverberated in the enzymatic saccharification step, in which $86 \%$ of the cellulose was converted to glucose in optimal conditions $(10 \% \mathrm{~S} / \mathrm{L}$ ratio, $50{ }^{\circ} \mathrm{C}, 60 \mu \mathrm{L} \mathrm{g}^{-1}$ cellulase, $15 \mathrm{~h}$ ). The efficiency of the fermentative process $(43.16$ $\mathrm{g} \mathrm{L}^{-1}$ of ethanol, $77 \%$ efficiency) was comparable with literature descriptions of ethanol production using lignocellulosic substrates. Furthermore, the execution of a fermentative 
process with a higher degree of control, and the detoxification of the saccharified buriti endocarp may contribute to enhance ethanol yield and viability.

\section{ADDITIONAL INFORMATION AND DECLARATIONS}

\section{Funding}

This study was supported by the Institutional Program of Scientific Initiation GrantsPIBIC of the Federal University of the Jequitinhonha and Mucuri Valleys and financed by the Foundation for Research Support of the State of Minas Gerais. The funders had no role in study design, data collection and analysis, decision to publish, or preparation of the manuscript.

\section{Grant Disclosures}

The following grant information was disclosed by the authors:

Institutional Program of Scientific Initiation Grants-PIBIC of the Federal University of the Jequitinhonha and Mucuri Valleys.

Foundation for Research Support of the State of Minas Gerais.

\section{Competing Interests}

The authors declare there are no competing interests.

\section{Author Contributions}

- Plínio R. Rodrigues conceived and designed the experiments, performed the experiments, analyzed the data, contributed reagents/materials/analysis tools, prepared figures and/or tables, authored or reviewed drafts of the paper, approved the final draft.

- Mateus F.L. Araújo and Tamarah L. Rocha performed the experiments.

- Ronnie Von S. Veloso analyzed the data, authored or reviewed drafts of the paper, approved the final draft, paper review.

- Lílian A. Pantoja analyzed the data, contributed reagents/materials/analysis tools, authored or reviewed drafts of the paper.

- Alexandre S. Santos conceived and designed the experiments, analyzed the data, contributed reagents/materials/analysis tools, prepared figures and/or tables, authored or reviewed drafts of the paper, approved the final draft.

\section{Data Availability}

The following information was supplied regarding data availability:

The raw data are included in the Supplemental Files.

\section{Supplemental Information}

Supplemental information for this article can be found online at http://dx.doi.org/10.7717/ peerj.5275\#supplemental-information. 


\section{REFERENCES}

Aditiya HB, Mahlia TMI, Chong WT, Nur H, Sebayang AH. 2016. Second generation bioethanol production: a critical review. Renewable and Sustainable Energy Reviews 66:631-653 DOI 10.1016/j.rser.2016.07.015.

Alrumman SA. 2016. Enzymatic saccharification and fermentation of cellulosic date palm wastes to glucose and lactic acid. Brazilian Journal of Microbiology 47:110-119 DOI 10.1016/j.bjm.2015.11.015.

Arantes V, Saddler JN. 2011. Cellulose accessibility limits the effectiveness of minimum cellulase loading on the efficient hydrolysis of pretreated lignocellulosic substrates. Biotechnology for Biofuels 4:1-16 DOI 10.1186/1754-6834-4-3.

Asada C, Sasaki C, Hirano T, Nakamura Y. 2015. Chemical characteristics and enzymatic saccharification of lignocellulosic biomass treated using high-temperature saturated steam: comparison of softwood and hardwood. Bioresource Technology 182:245-250 DOI 10.1016/j.biortech.2015.02.005.

Azelee NIW, Jahim JM, Rabu A, Murad AMA, Bakar FDA, Illias RM. 2014. Efficient removal of lignin with the maintenance of hemicellulose from kenaf by two-stage pretreatment process. Carbohydrate Polymers 99:447-453 DOI 10.1016/j.carbpol.2013.08.043.

Barliante V, Dahnum D, Hendarsyah H, Abimanyu H. 2015. Effect of alkaline pretreatment on properties of lignocellulosic oil palm waste. Precedia Chemistry 16:195-201 DOI 10.1016/j.proche.2015.12.036.

Bos HL, Meesters KPH, Conijn SG, Corré WJ, Patel MK. 2016. Comparing biobased products from oil crops versus sugar crops with regard to non-renewable energy use, GHG emissions and land use. Industrial Crops and Products 84:366-374 DOI 10.1016/j.indcrop.2016.02.013.

Bovi GG. 2015. Óleo de buriti (Mauritia flexuosa L) nanoemulsionado: produção por método de baixa energia, caracterização físico-química das dispersões e incorporação em bebida isotônica. MSc dissertation, São Paulo University. Available at http: //www.teses.usp.br/teses/disponiveis/74/74132/tde-02022016-102410/pt-br.php.

Chieng BW, Lee SH, Ibrahim NA, Then YY, Loo YY. 2017. Isolation and characterization of cellulose nanocrystals from oil palm mesocarp fiber. Polymers 9:1-11 DOI 10.3390/polym9080355.

Corbin KR, Hsieh YSY, Betts NS, Byrt CS, Henderson M, Stork J, DeBolt S, Fincher GB, Burton RA. 2015. Grape marc as a source of carbohydrates for bioethanol: chemical composition, pre-treatment and saccharification. Bioresource Technology 193:76-83 DOI 10.1016/j.biortech.2015.06.030.

Dardick C, Callahan AM. 2014. Evolution of the fruit endocarp: molecular mechanisms underlying adaptations in seed protection and dispersal strategies. Frontiers in Plant Science 5:106-115 DOI 10.3389/fpls.2014.00284.

Deshavath NN, Mohan M, Veeranki VD, Goud VV, Pinnamaneni SR, Benarjee T. 2017. Dilute acid pretreatment of sorghum biomass to maximize the hemicellulose hydrolysis with minimized levels of fermentative inhibitors for bioethanol production. 3 Biotech 7:1-12 DOI 10.1007/s13205-017-0752-3. 
Domínguez-Bocanegra AR, Torres-Muñoz JA, López RA. 2015. Production of bioethanol from agro-industrial wastes. Fuel 149:85-89

DOI 10.1016/j.fuel.2014.09.062.

Gilmore MP, Endress BA, Horn CM. 2013. The socio-cultural importance of Mauritia flexuosa palm swamps (aguajales) and implications for multi-use management in two Maijuna communities of the Peruvian Amazon. Journal of Ethnobiology Ethnomedicin 9:1-23 DOI 10.1186/1746-4269-9-29.

Gonzales RR, Sivagurunathan P, Kim S-H. 2016. Effect of severity on dilute acid pretreatment of lignocellulosic biomass and the following hydrogen fermentation. International Journal of Hydrogen Energy 41:21678-21684 DOI 10.1016/j.ijhydene.2016.06.198.

Guo H, Chang Y, Lee D-J. 2018. Enzymatic saccharification of lignocellulosic biorefinery: research focuses. Bioresource Technology 252:198-215

DOI 10.1016/j.biortech.2017.12.062.

Handley LW, Pharr DM, McFeeters RF. 1983. Carbohydrate changes during maturation of cucumber fruit: implications for sugar metabolism and transport. Plant Physiology 72:498-502 DOI 10.1104/pp.72.2.498.

Hoa DP, Ngob HH, Guo W. 2014. A mini review on renewable sources for biofuel. Bioresource. Technology 169:742-749 DOI 10.1016/j.biortech.2014.07.022.

IAL-Instituto Adolfo Lutz. 2008. Normas Analíticas do Instituto Adolfo Lutz. Métodos químicos e físicos para análise de alimentos. 4th edition. São Paulo: Instituto Adolfo Lutz.

Isarankura-Na-Ayudhya $C$, Tantimongcolwat T, Kongpanpee T, Prabkate $P$, Prachayasittikul V. 2007. Appropriate technology for the bioconversion of water hyacinth (Eichhornia crassipes) to liquid ethanol: future prospects for community strengthening and sustainable development. EXCLI Journal 6:167-176 DOI 10.17877/DE290R-344.

Jing-Ping G, Bai-Yan C, Guo-Ming L, Hong-Zhi L, Bao-Zhu F, Gang S, Xiao-Feng Y, Wen-Xiang P. 2011. Comparison of different detoxification methods for corn cob hemicelluose hydrolysate to improve ethanol production by Candida shehatae ACCC 20335. African Journal of Microbiology Research 5:1163-1168 DOI 10.5897/AJMR10.744.

Kamer SBV, Ginkel VL. 1952. Rapid determination of crude fiber in cereals. Cereal Chemisty 375(19):239-251.

Kamoldeen AA, Keong LC, Abdullah WNW, Peng LC. 2017. Enhanced ethanol production from mild alkali-treated oil-palm empty fruit bunches via co-fermentation of glucose and xylose. Renewable Energy 107:113-123 DOI 10.1016/j.renene.2017.01.039.

Ko JK, Um Y, Woo HM, Kim KH, Lee SM. 2016. Ethanol production from lignocellulosic hydrolysates using engineered Saccharomyces cerevisiae harboring xylose isomerase-based pathway. Bioresource Technology 209:290-296 DOI 10.1016/j.biortech.2016.02.124.

Koti S, Govumoni SP, Gentela J, Rao LV. 2016. Enhanced bioethanol production from wheat straw hemicellulose by mutant strains of pentose fermenting organisms Pichia stipitis and Candida shehatae. Springerplus 5:1-9 DOI 10.1186/s40064-016-3222-1. 
Liu X, Xu W, Mao L, Zhang C, Yan P, Xu Z, Zhang ZC. 2016. Lignocellulosic ethanol production by starch-base industrial yeast under PEG detoxification. Scientific Reports 6:20361 DOI 10.1038/srep20361.

Lloyd JB, Whelan WJ. 1969. An improved method for enzymic determination of glucose in the presence of maltose. Analytical Biochemistry 30:467-470 DOI 10.1016/0003-2697(69)90143-2.

Lorenzi H, Souza HM, Cerqueira LSC, Medeiros-Costa JT, Ferreira E. 2004. Palmeiras brasileiras e exóticas cultivadas. 1st edition. São Paulo: Instituto Plantarum.

Macedo AL, Santos RS, Pantoja LA, Santos AS. 2011. Pequi cake composition, hydrolysis and fermentation to bioethanol. Brazilian Journal of Chemical Engineering 28:9-15 DOI 10.1590/S0104-66322011000100002.

Manzi M, Coomes OT. 2009. Managing Amazonian palms for community use: a case of aguaje palm (Mauritia flexuosa) in Peru. Forest Ecology and Management 257:510-517 DOI 10.1016/j.foreco.2008.09.038.

Maurya DP, Singla A, Negi S. 2015. An overview of key pretreatment processes for biological conversion of lignocellulosic biomass to bioethanol. 3 Biotech 5:597-609 DOI 10.1007/s13205-015-0279-4.

Mccready RM, Guggolz J, Silviera VE, Owens HS. 1950. Determination of starch and amylose in vegetables. Analytical Chemistry 22:1156-1158 DOI 10.1021/ac60045a016.

Mendu V, Harman-Ware AE, Crocker M, Jae J, Stork J, Morton S, Placido A, Huber G, Debolt S. 2011. Identification and thermochemical analysis of high lignin feedstocks for biofuel and bio-chemical production. Biotechnology for Biofuels 4:1-13 DOI 10.1186/1754-6834-4-43.

Miller GL. 1959. Use of dinitrosalicylic acid reagent for determination of reducing sugar. Analytical Chemistry 31:426-428 DOI 10.1021/ac60147a030.

Saini JK, Saini R, Tewari L. 2015. Lignocellulosic agriculture wastes as biomass feedstocks for second-generation bioethanol production: concepts and recent developments. 3 Biotech 5:337-353 DOI 10.1007/s13205-014-0246-5.

Saka S, Munusamy MV, Shibata M, Tono Y, Miyafuji H. 2008. Chemical constituents of the different anatomical parts of the oil palm (Elaeis guineensis) for their sustainable utilization. In: JSPS-VCC group seminar 2008, natural resources and energy environment, 24-25 November, Kyoto, Japan. Available at http://vixra.org/pdf/1411.0089v1. $p d f$.

Sampaio MB, Carrazza LR. 2012. Manual Tecnológico de Aproveitamento Integral do Fruto e da Folha do Buriti (Mauritia flexuosa). 1st edition. Brasília: ISPN.

Sarkar N, Ghosh SK, Bannerjee S, Aikat K. 2012. Bioethanol production from agricultural wastes: an overview. Renew Energy 37:19-27 DOI 10.1016/j.renene.2011.06.045.

Severo EA, Guimarães JCF, Dorion ECH. 2018. Cleaner production, social responsibility and eco-innovation: generations' perception for a sustainable future. Journal of Cleaner Production 186:91-103 DOI 10.1016/j.jclepro.2018.03.129.

Shen J, Agblevor FA. 2008. Optimization of enzyme loading and hydrolytic time in the hydrolysis of mixtures of cotton gin waste and recycled paper sludge for the maximum profit rate. Biochemical Engineering Journal 41:241-250 DOI 10.1016/j.bej.2008.05.001. 
Sims REH, Mabee W, Saddler JN, Taylor M. 2009. An overview of second generation biofuel technologies. Bioresource Technology 101:1570-1580

DOI 10.1016/j.biortech.2009.11.046.

Singleton VL, Rossi JA. 1965. Colorimetric of total phenolics with phosphomolybdicphosphotungstic acid reagents. American Journal Enology and Viticulture 16:144-146.

United Nations Conference on Trade and Development (UNCTAD). 2016. Second generation biofuel markets: state of play and developing countries perspectives. UNITED NATIONS PUBLICATION Copyright (C) United Nations Available at http:// unctad.org/en/PublicationsLibrary/ditcted2015d8_en.pdf (accessed on 22 August 2017).

Van SF, Brose I, Schenkel Y. 2011. Direct and indirect land use changes issues in European sustainability initiatives: State of-the-art, open issues and future developments. Biomass and Bioenergy 35:4824-4834 DOI 10.1016/j.biombioe.2011.07.015.

Van Soest PJ. 1963. Use of detergents in the analysis of fibrous feeds II. A rapid method of the determination of fiber and lignin. Journal of the Association of Official Agricultural Chemists 26:829-835.

Van Soest PJ. 1964. Symposium on nutrition and forage and pastures: new chemical procedures for evaluating forages. Journal of Animal Science 23:838-845 DOI 10.2527/jas1964.233838x.

Van Soest PJ. 1968. Determination of lignin and cellulose in acid detergent fiber with permanganate. Journal of the Association of Official Analytical Chemists 51:780-785.

Varanasi P, Singh P, Auer M, Adams P, Simmons B, Singh S. 2013. Survey of renewable chemicals produced from lignocellulosic biomass during ionic liquid pretreatment. Biotechnology for Biofuels 6:1-9 DOI 10.1186/1754-6834-6-14.

Virapongse A, Endress BA, Gilmore MP, Horn C, Romulo C. 2017. Ecology, livelihoods, and management of the Mauritia flexuosa palm in South America. Global Ecology and Conservation 10:70-92 DOI 10.1016/j.gecco.2016.12.005.

Woo KS, Kim HY, Hwang G, Lee SH, Jeong HS. 2015. Characteristics of the thermal degradation of glucose and maltose solutions. Preventive Nutrition and Food Science 20:102-109 DOI 10.3746/pnf.2015.20.2.102.

Zabed H, Sahu JN, Boyce AN, Faruq G. 2016. Fuel ethanol production from lignocellulosic biomass: an overview on feedstocks and technological approaches. Renewable and Sustainable Energy Reviews 66:751-774 DOI 10.1016/j.rser.2016.08.038.

Zhang B, Wang L, Shahbazi A, Diallo O, Whitmore A. 2011. Dilute-sulfuric acid pretreatment of cattails for cellulose conversion. Bioresource Technology 102:9308-9312 DOI 10.1016/j.biortech.2011.07.008.

Zhang J, Zhu Z, Wang X, Wang N, Wang W, Bao J. 2010. Biodetoxification of toxins generated from lignocellulose pretreatment using a newly isolated fungus, Amorphotheca resinae $\mathrm{ZN1}$, and the consequent ethanol fermentation. Biotechnology for Biofuels 3:1-15 DOI 10.1186/1754-6834-3-26. 